\title{
Cooperation for innovation in developing countries and its effects: evidence from Ecuador
}

\author{
Juan Fernández Sastre ${ }^{1 *}$, César Eduardo Vaca Vera ${ }^{1}$
}

\begin{abstract}
This paper evaluates the impact of the most common innovation linkages by type of innovation activity on firms' innovation inputs and outputs. In order to estimate the casual effects, we employ Inverse Probability Weighting, while focusing on exclusive cooperative agreements to prevent our results from being affected by the presence of additional relationships in other activities or with other types of partners. Results indicate that cooperation in non-R\&D innovation activities positively affects the introduction of new-to-the-firm product, marketing and organizational innovations, while cooperation in both $\mathrm{R} \& \mathrm{D}$ and non-R\&D activities also affects R\&D intensity and new-to-the-market product innovation. Furthermore, firms that cooperate exclusively in obtaining information, which is mainly carried out with suppliers and customers, are more likely to introduce new-to-the-firm product and organizational innovations.
\end{abstract}

Keywords: non-R\&D cooperation; technological capabilities; impact assessment.

Abstract: This paper evaluates the impact of the most common innovation linkages by type of innovation activity on firms' innovation inputs and outputs. In order to estimate the casual effects, we employ Inverse Probability Weighting, while focusing on exclusive cooperative agreements to prevent our results from being affected by the presence of additional relationships in other activities or with other types of partners. Results indicate that cooperation in non-R\&D innovation activities positively affects the introduction of new-to-the-firm product, marketing and organizational innovations, while cooperation in both $R \& D$ and non- $\&$ D activities also affects R\&D intensity and new-to-the-market product innovation. Furthermore, firms that cooperate exclusively in obtaining information, which is mainly carried out with suppliers and customers, are more likely to introduce new-to-the-firm product and organizational innovations.

Keywords: non-R\&D cooperation; technological capabilities; impact assessment.

Submitted: May 16 2017 / Approved: September 22 2017

\section{Introduction}

Empirical studies on networks of innovators focus on the effects of cooperation in R\&D activities (Sánchez-González, 2014; FernándezSastre, 2015). Nonetheless, if one aims at analyzing the effects of cooperation in less-developed countries, cooperative agreements in non-R\&D innovation activities should also be considered, as in these contexts innovation is mostly related to the absorption of technology and competence building rather than to science-based R\&D (Chaminade et al., 2010).

Although there are studies assessing the effects of $\mathrm{R} \& \mathrm{D}$ cooperation in developing countries (Temel et al., 2013; Sousa et al., 2015), there is no evidence relating to the impact of cooperation in non-R\&D innovation activities, because innovation surveys just provide information on $\mathrm{R} \& \mathrm{D}$ cooperation. In this regard, the Ecuadorian Survey of Innovation 2013 (ENAI) is a notable exception as it also distinguishes between cooperation in the following innovation activities: engineering and design, training, technical assistance, information and product testing.

Drawing on data from the ENAI 2013, this paper establishes the most common innovation activities in which Ecuadorian firms cooperate in order to estimate their effects on firms' innovation inputs and outputs. The remainder of this paper is organized as follows. Section 2 reviews the literature background for our analysis. Section 3 proceeds by describing the data and the variables. Section 4 explains the methodology. Section 5 discusses the implications of the empirical results. Finally, we conclude in Section 6.

\section{Literature review}

Firms differ in their technical skills and in the way they master new technologies and improve upon them (Lall, 1992). As a result they employ different learning mechanisms to acquire knowledge depending on the level of the technological capabilities they have accumulated (Figueiredo, 2001; Divella, 2017).

In the case of developing countries, most firms are still not prepared to innovate and they coexist with other firms that have developed more successful capabilities (Molina-Domene and Pietrobelli, 2012). Therefore, in these countries, most cooperative relationships are often not associated with $\mathrm{R} \& \mathrm{D}$ but have the objectives of obtaining information and carrying out training activities (Anlló and Suárez, 2008). These activities are also sources of innovation (Zhou and $\mathrm{Wu}$, 2010) and by the establishment of cooperative agreements, firms may

(1) Latin American Faculty of Social Sciences (FLACSO), Quito, Ecuador.

* E-mail: jfernandez@flacso.edu.ec 
increase their capabilities which could have an impact on both their innovation inputs and outputs. Nevertheless, these types of agreements may be used by firms to build basic capabilities in order to engage in innovation later on, which could delay their effects.

Cooperative agreements in non- $\mathrm{R} \& \mathrm{D}$ activities are likely to increase investment in non-R\&D innovation activities, but they may also induce firms to invest in $R \& D$ as these agreements may allow firms to develop technological capabilities over which they can construct the R\&D capabilities that are decisive to perform R\&D (Chaminade and Vang, 2008). Additionally, we also expect that the firms with these types of agreements are more likely to create new methods, processes and products. However, as these activities are mostly related to the absorption of technology, we expect that their linkages will produce greater effects on new-to-the-firm innovations rather than in the introduction of new-to-the-market innovations.

Furthermore, as there is evidence that R\&D cooperation has positive effects on firms' ability to introduce organizational and marketing innovations (Sánchez-González, 2014; Simao and Franco, 2015), we are also interested in evaluating whether non-R\&D cooperation also has an effect on them. Furthermore, we are interested in evaluating whether the combination of $R \& D$ and non- $R \& D$ linkages produces additional effects, as there may be complementarities between the two.

Lastly, as the effects of cooperation may differ depending on the type of partner with which the firms cooperate (Shin et al., 2016), we also need to take into account that the cooperative agreements of firms in developing countries not only differ from those of the developed world in terms of the type of activities, but also in the type of partners with which these agreements are established. For instance, in developing countries only a small proportion of the firms have developed cooperative agreements with science and technology institutions and the most common links are established with customers and suppliers and to a lesser extent with competitors (Anlló and Suárez, 2008).

\section{Data and variables}

We use data from the ENAI 2013 which contains information on 2,815 firms for the period 2009-2011. However, our analysis only covers 1,521 innovative firms as they are the only ones that answer the question on cooperation.

In relation to cooperation variables, ENAI provides information on the type of innovation activity in which firms cooperate (R\&D, engineering and design, training, technical assistance, information and product testing) and on the type of partner (suppliers, clients, competitors, universities, laboratories and $\mathrm{R} \& \mathrm{D}$ firms, public organizations of science and technology). Although by combining this information we can create different types of cooperation variables, if one is aiming to analyze the impact of cooperation two aspects should be taken into account. First, it is important to be aware of the presence of potential hidden treatments (Guerzoni and Raiteri, 2015), as there are firms that collaborate in several activities with different partners at the same time. Thus, a hidden treatment might be represented by an additional cooperative agreement that can be used by the firm to obtain the same results. Therefore, if this is not taken into account, it is impossible to conclude that the observed innovation outcome is due to a specific cooperative agreement or to the use of another non-considered relationship or to the interaction of diverse cooperative agreements. To deal with this issue, we have decided to evaluate the impact of cooperation for firms that have exclusively one type of cooperative relationship. Second, in order to obtain credible standard errors we need to evaluate the impact of the cooperative agreements for which there are a sufficient number of cooperating firms. Table 1 shows the frequency of the exclusive cooperation variables for which we have a sufficient number of observations which will constitute our treatment variables.

Table 1. Exclusive cooperation variables with a sufficient number of observations

\begin{tabular}{lc}
\hline & Frequency \\
\hline Only non-R\&D cooperation & 1198 \\
R\&D and non-R\&D cooperation & 97 \\
Only cooperation in information & 409 \\
Only vertical non-R\&D cooperation & 733 \\
Only vertical cooperation in information & 228 \\
\hline
\end{tabular}

Source: ENAI 2009-2011

Non-R\&D cooperation refers to cooperation in the following innovation activities: engineering and design, training, technical assistance, information and product testing.

Vertical refers to suppliers and customers

As a starting point, we will assess the effects of two exclusive aggregate measures of cooperation. The first treatment is Only non-R\&D cooperation which takes value 1 for firms that have at least a cooperative agreement in a non-R\&D activity with any type of partner but that are not cooperating in $\mathrm{R} \& \mathrm{D}$ and 0 for firms that do not cooperate at all. The second variable is $R \leftrightarrow D$ and non-R\&D cooperation taking on 1 for firms that collaborate in R\&D with any type of partner and that also have at least a cooperative agreement in a non-R\&D activity and 0 for non-cooperating firms. Note that we do not evaluate the impact of Only Re D cooperation as in our sample there are only 8 firms with this pattern. This shows that in the context of a developing country, $\mathrm{R} \& \mathrm{D}$ cooperation is only a marginal phenomenon although cooperation in non- $\mathrm{R} \& \mathrm{D}$ activities is widespread among innovative firms.

Then we evaluate the impact of the most frequent cooperation linkages by type of non-R\&D activity. However, we only have a sufficient number of observations to evaluate the impact of cooperation in obtaining information as in developing countries the majority of the firms are in the first stage of the process of building technological capabilities to innovate which consists of accumulating the minimum essential knowledge base (Dutrénit, 2004). Thus, the third treatment is Only cooperation in information which takes value 1 for firms that cooperate exclusively in obtaining information regardless the type of partner and 0 for non-cooperating firms. 
Finally, we aim at evaluating the impact of the most frequent cooperation agreements by type of non-R\&D innovation activity and type of partner. In this case we only observe a substantial number of cooperating firms for vertical partners (clients and suppliers). We shall therefore analyze the impact of cooperation with vertical partners in non-R\&D innovation activities and with vertical partners in obtaining information. We will refer to the former treatment as Only vertical non-R\&D cooperation, which takes value 1 for firms that cooperate exclusively with clients or suppliers in at least one non-R\&D innovation activity and 0 for non-cooperating firms; while the latter will be named Only vertical cooperation in information, taking on 1 for firms that cooperate exclusively with clients or suppliers in obtaining information and 0 for firms that do not cooperate at all. Note that all cooperation variables refers to the period 2009-2011.

Regarding outcome variables, we consider two innovation inputs and 6 outputs. Innovation inputs are R\&D intensity, which is measured as the natural logarithm of 1 plus internal and external R\&D expenditures divided by the total number of employees, all measured in 2011, and Non-R\&D intensity, which is measured as the natural logarithm of 1 plus investments in the acquisition of machinery and equipment, of hardware, of software, of disembodied technology, contracting of consultancies and technical assistance, engineering and industrial design, staff training and market studies divided by the total number of employees, all measured in 2011 . While for innovation outputs we consider the following dichotomous variables: new to the market product, new to the firm product, new to the market process, new to the firm process, organizational innovation and marketing innovation. These variables take value 1 if the firm introduced the specific innovation during the period 20092011 and 0 otherwise.

\section{Methodology}

Given that firms select themselves into cooperation, it is unlikely that firms that cooperate have the same characteristics as other firms. Moreover, if the characteristics that influence the cooperation decision also condition the outcome variables, the estimated coefficients of cooperation would be biased. Thus, in order to obtain the causal effect of cooperation, we employ inverse probability weighting (IPW) (Hirano et al., 2003) which is a propensity score method (Rubin and Rosenbaum, 1983). The propensity score is the conditional probability that a firm has selected itself to cooperation given an observed set of covariates. Once the propensity score is estimated through a probit model, IPW estimates the average treatment effect on the treated (ATT) by weighting cooperating firms by the inverse propensity score and non-cooperating firms by the inverse of 1 minus their propensity score (Rosenbaum, 2005). By doing this, IPW creates a pseudopopulation in which the covariates and the treatment assignment are independent of each other. Once propensity scores are calculated, the ATT may be estimated using a regression model that incorporates the weights.

The success of IPW in estimating the ATT relies on two assumptions. The first, known as unconfoundedness, implies that the distribution of each potential outcome is independent of the random treatment, conditional on the covariates. Therefore, it requires the absence of any unobserved confounders and a high degree of post-match balance across observable covariates. The first requirement is untestable but it requires the propensity score model to include an adequate set of covariates. In this sense, it is more important to include either those covariates related to outcomes or those related to treatment and outcomes than to include those variables that affect exclusively the treatment-selection process (Austin et al., 2007). Consequently, in the estimations of the different propensity scores, we include in the vector of covariates an important set of factors that may influence both cooperation and outcome variables. Additionally, as the unconfoundedness assumption is not directly testable, its plausibility can often be assessed using lagged values of the outcomes as pseudo outcomes (Imbens, 2015); thus, we include the lagged values of R\&D intensity and Non-R\&D intensity both measured in 2009. Appendix 1 describes the set of covariates included in the propensity score equations and Appendix 2 shows the results of the probit models for the different types of cooperation variables.

As mentioned above, in order to show that the unconfoundedness assumption may hold, it is important to check whether IPW has generated a post-match balance across observable covariates. To show this, Table 2 indicates the model-adjusted difference in means and ratio of variances between the treated and untreated for each covariate for the treatments Only non-R\&D cooperation and R\&D and non-R\&D cooperation (Appendix 3 displays the balance tests for the rest of the cooperation variables which show that differences in weighted means are negligible and that variance ratios are all near one, indicating that balance was successful for these treatments). 
Tabla 2. Covariates balance test

\begin{tabular}{|c|c|c|c|c|c|c|c|c|}
\hline & \multicolumn{4}{|c|}{ Only non-R\&D Cooperation } & \multicolumn{4}{|c|}{$R \& D$ and non-R\&D Cooperation } \\
\hline & \multicolumn{2}{|c|}{ Standardized differences } & \multicolumn{2}{|c|}{ Variance ratio } & \multicolumn{2}{|c|}{ Standardized differences } & \multicolumn{2}{|c|}{ Variance ratio } \\
\hline & Before IPW & After IPW & Before IPW & After IPW & Before IPW & After IPW & Before IPW & After IPW \\
\hline Non-R\&D intensity_2009 & 0.170 & -0.029 & 1.119 & 1.002 & 0.587 & -0.010 & 1.059 & 0.993 \\
\hline Size & -0.093 & 0.034 & 0.942 & 1.078 & 0.374 & 0.118 & 1.342 & 0.932 \\
\hline Exporter & -0.072 & 0.013 & 0.867 & 1.027 & 0.204 & 0.010 & 1.358 & 1.012 \\
\hline Group & -0.004 & 0.026 & 0.987 & 1.058 & 0.130 & 0.061 & 1.280 & 1.112 \\
\hline Qualification & -0.093 & 0.002 & 0.735 & 1.008 & 0.149 & 0.043 & 1.467 & 1.102 \\
\hline Sectorial cooperation & 0.133 & -0.009 & 0.953 & 1.080 & 0.273 & -0.035 & 0.875 & 1.265 \\
\hline
\end{tabular}

As we can see, before applying IPW differences were large. However, after applying IPW differences in weighted means are negligible, and variance ratios are all near one. This indicates that we have a high degree of post-match balance across our observable covariates. However, after weighting, we obtain a better balance on observables for the treatment Only non-R\&D cooperation than for R\&D and non-R\&D cooperation. In the case of the latter, we still observe differences between treated and controls in relation to the variables Size and Start-up.

An alternative way of checking for good balance on observable covariates after applying IPW is to perform a chi square overidentification test in which null hypothesis considers that the covariates are balanced. Table 3 displays these tests for the different treatment variables.

Table 3. Covariates chi square balance test

\begin{tabular}{lc}
\hline \multicolumn{1}{c}{ Treatment } & Chi square \\
\hline \multirow{2}{*}{ Only non-R\&D cooperation } & 8.518 \\
& $(0.666)$ \\
\hline \multirow{2}{*}{ Only R\&D and non-R\&D cooperation } & 12.751 \\
& $(0.310)$ \\
\hline Only cooperation in information & 3.890 \\
Only vertical non-R\&D cooperation & $(0.973)$ \\
\hline \multirow{2}{*}{ Only vertical cooperation in information } & 7.900 \\
& $(0.722)$ \\
\hline
\end{tabular}

As we can see from Table 3, we cannot reject the null hypothesis that the covariates are balanced indicating that IPW has been successful in balancing covariates for all the different treatments.

The second assumption is the overlap assumption which states that each firm has a positive probability of cooperating. This ensures that we have enough firms with the same covariates in both groups (treated and control). A common way of checking for this is to compare the estimated densities of the probability of getting each treatment of the treated group with that of the controls. Figure 1 shows these densities for our different treatment variables.
Figure 1. Estimated densities of the probability of cooperating
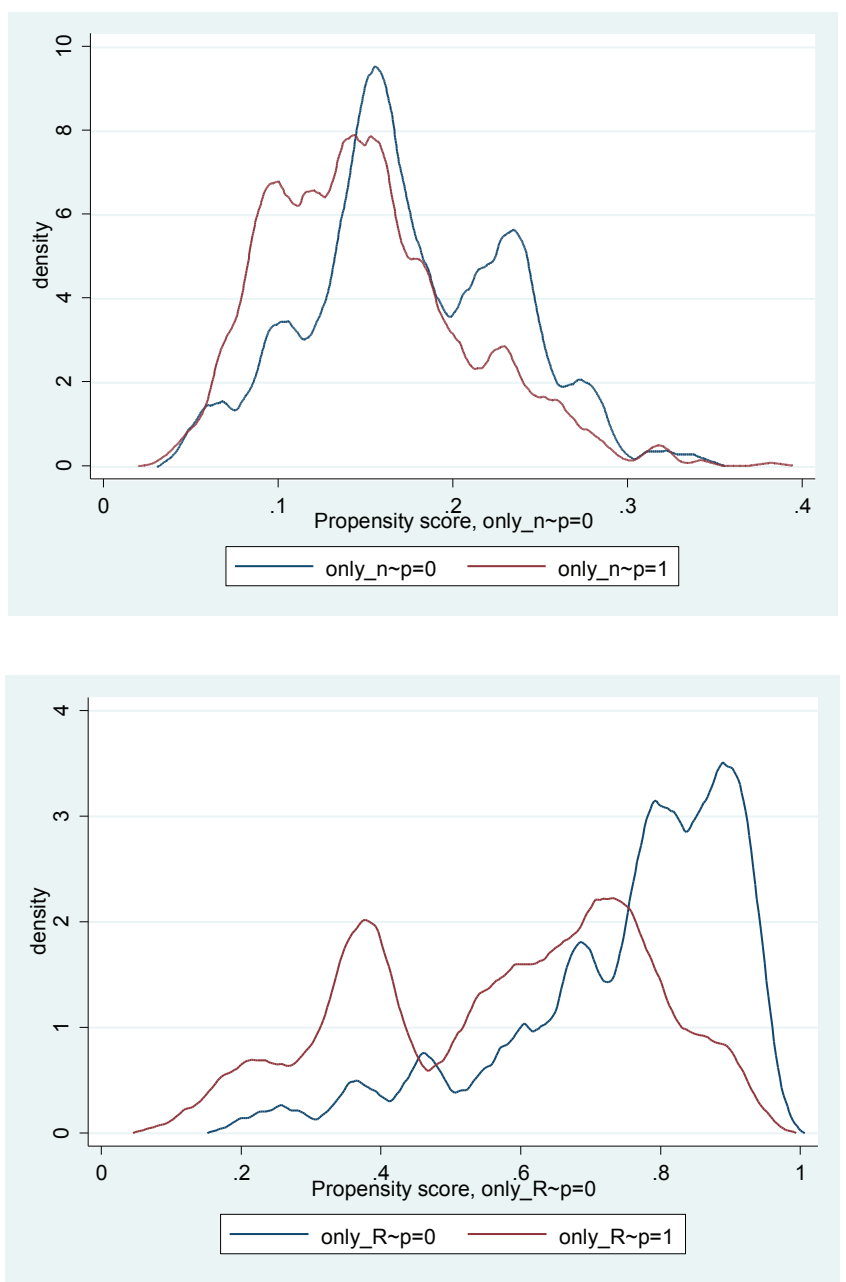

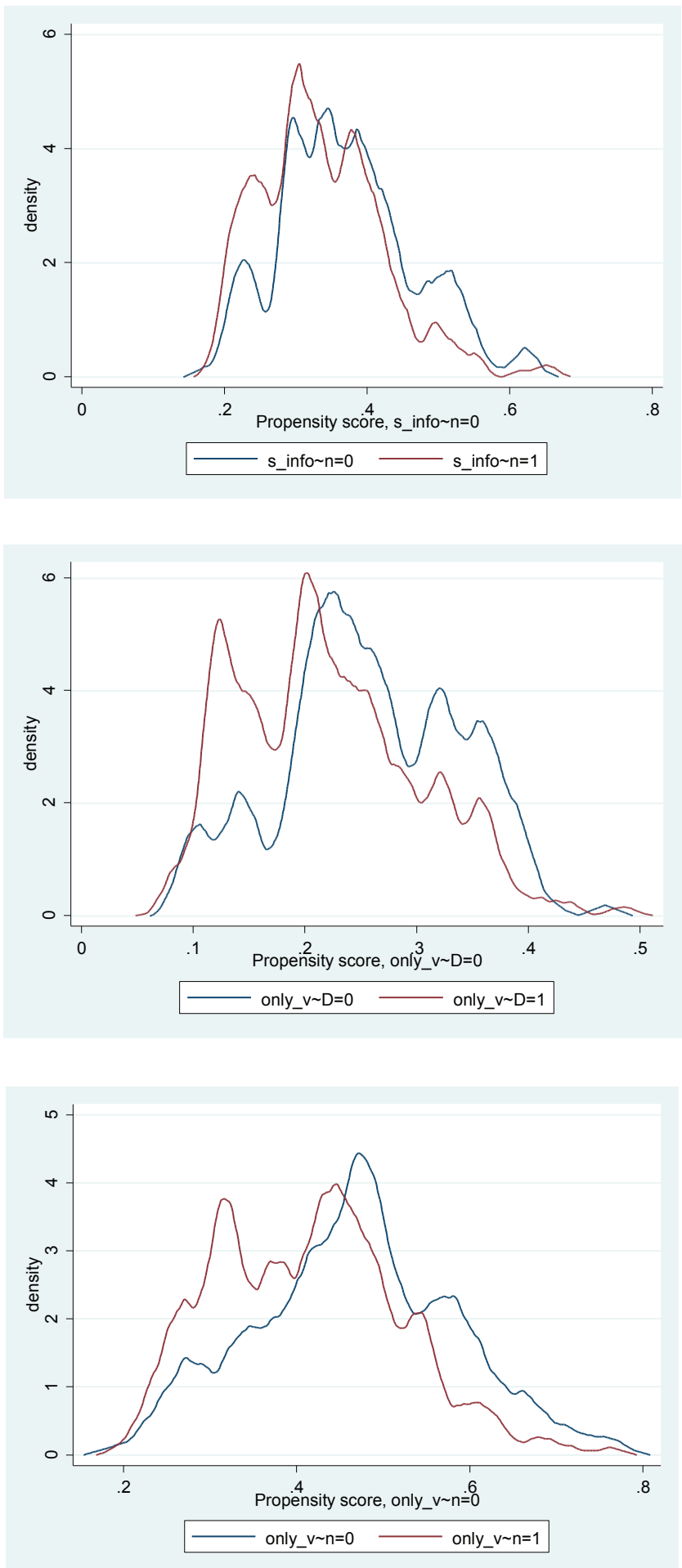

From top to bottom and left to right: Only non-R\&D cooperation, R\&D and non- $\mathrm{R} \& \mathrm{D}$ cooperation, Only cooperation in information, Only vertical nonR\&D cooperation, Only vertical cooperation in information.

As we can see from the different graphs, neither plot indicates too much probability mass near 0 or 1 and that for every treatment the two estimated densities have most of their respective masses in regions in which they overlap each other. Therefore there is no evidence that the overlap assumption is violated.

\section{Empirical results}

Table 4 displays the ATT for the treatments Only non-R\&D cooperation and R\&D and non-R\&D cooperation on the different types of innovation inputs and outputs.

Table 4. Impact of non- $R \& D$ cooperation and $R \& D$ and non- $R \& D$ cooperation (ATT) on the innovation inputs and outputs.

\begin{tabular}{lcc}
\hline Only non-R\&D & $\begin{array}{c}\text { R\&D and non-R\&D } \\
\text { cooperation }\end{array}$ & 1.318 \\
\hline R\&D intensity & -0.250 & $(0.376)^{* * *}$ \\
Non-R\&D intensity & $(0.187)$ & 0.714 \\
New to the market & 0.079 & $(0.384)^{*}$ \\
product & 0.033 & 0.198 \\
New to the firm & $(0.036)$ & $(0.069)^{* * *}$ \\
product & 0.188 & 0.158 \\
New to the market & $(0.039)^{* * *}$ & $(0.071)^{* *}$ \\
process & 0.006 & 0.103 \\
New to the firm & $(0.036)$ & $(0.071)$ \\
process & 0.020 & 0.124 \\
Organizational & $(0.039)$ & $(0.071)^{*}$ \\
innovation & 0.093 & 0.178 \\
Marketing inno- & $(0,036)^{* *}$ & $(0,072)^{* *}$ \\
vation & 0.088 & 0.212 \\
\hline
\end{tabular}

Notes: ${ }^{*}$ significant at $10 \%,{ }^{* *}$ significant at $5 \%,{ }^{* * *}$ significant at $1 \%$

Regarding the impact on innovation inputs, results indicate that cooperation only in non-R\&D activities does not affect either expenditures in $R \& D$ or in non- $\& \& D$ activities. By contrast, the combination of $R \& D$ and non-R\&D networks stimulates both types of investments. This indicates that non-R\&D collaborative agreements are not enough to build the technological capabilities that induce firms to invest more in innovation activities, unless they are combined with cooperation in $R \& D$ activities. These results suggest that non-R\&D linkages may be used by firms to build the minimum essential knowledge base to survive in the market and that during this process firms seem to postpone their investments in innovation activities probably until they have built advanced technological capabilities in technical functions and complex knowledge bases (Dutrénit, 2004). By contrast, firms that are also cooperating in $R \& D$ activities seem to be using their networks to nurture and renew strategic capabilities, which leads them to invest more in R\&D and in other innovation activities. Therefore, firms need to cooperate in $\mathrm{R} \& \mathrm{D}$ activities in order to develop the technological capabilities that are required to encourage innovation.

In relation to the effects of these two treatments on product innovation, results indicate that cooperation only in non-R\&D activities increases the likelihood of introducing new-to-the-firm products, while the combination of $R \& D$ and non-R\&D cooperation enables the introduction of new-to-the-market and new-to-the-firm products. 
Therefore, non-R\&D linkages seem to be used by the firms to accumulate the necessary knowledge to introduce products that already exist in the market but that the firms do not have sufficient knowledge and capabilities to produce by themselves. By contrast, R\&D cooperation seems to be orientated towards the introduction of products that are not yet on the market, which is not surprising as more radical innovations normally require investments in $\mathrm{R} \& \mathrm{D}$ activities and the use of a large variety of sources of information and collaborative agreements with external partners (Landry and Amara, 2002; De Faria, et al., 2010)

Results also indicate that cooperation only in non-R\&D activities does not produce a significant impact on any type of process innovation, while $R \& D$ and non- $\& \& D$ cooperation increases the likelihood of introducing new-to-the-firm processes, although the effect is only significant at $90 \%$. This indicates that cooperative agreements in Ecuador are clearly more orientated towards the improvement of quality rather than the reduction of costs.

Finally, both treatments increase the likelihood of introducing marketing and organizational innovations, which is not surprising given that collaborative agreements are mainly established with customers and suppliers. As Radicic et al. (2015) indicate, while cooperation with customers can be of primary relevance for marketing innovations, cooperation with suppliers could be more focused on organizational innovations. In addition, it is important to highlight that the effects on marketing and organizational innovations are clearly greater for the treatment R\&D and non-R\&D cooperation than for Only non-R\&D cooperation which indicates that there are complementarities between $\mathrm{R} \& \mathrm{D}$ and non-R\&D cooperation when it comes to nontechnological innovations.

Although the results discussed above give some insights on the effects of non-R\&D cooperation in developing countries, they could be somewhat misleading, as cooperation in non- $R \& D$ activities includes a diverse set of activities that could have different effects on the inputs and outputs of the innovation process. In the same way, these different activities may be carried out with a variety of partners and it is also likely that different partners produce dissimilar effects (Shin et al., 2016). Consequently, Table 5 displays the ATT for the different exclusive cooperation variables by type of non-R\&D innovation activity and by type of partner.
Table 5. Impact of cooperation by type of partner and innovation activity (ATT) on the innovation inputs and outputs.

\begin{tabular}{|c|c|c|c|}
\hline & $\begin{array}{c}\text { Only } \\
\text { cooperation in } \\
\text { information }\end{array}$ & $\begin{array}{c}\text { Only vertical } \\
\text { non } R \& D \\
\text { cooperation }\end{array}$ & $\begin{array}{c}\text { Only vertical } \\
\text { cooperation in } \\
\text { information }\end{array}$ \\
\hline \multirow{2}{*}{$\begin{array}{l}\text { R\&D } \\
\text { intensity }\end{array}$} & -0.334 & -0.279 & -0.316 \\
\hline & $(0.182)^{\star}$ & $(0.186)$ & $(0.201)$ \\
\hline \multirow{2}{*}{$\begin{array}{l}\text { Non-R\&D } \\
\text { intensity }\end{array}$} & 0.015 & 0.069 & 0.138 \\
\hline & $(0.233)$ & $(0.225)$ & $(0.253)$ \\
\hline \multirow{2}{*}{$\begin{array}{l}\text { New to } \\
\text { the market } \\
\text { product }\end{array}$} & 0.021 & 0.018 & 0.009 \\
\hline & $(0.039)$ & $(0.038)$ & $(0.043)$ \\
\hline \multirow{2}{*}{$\begin{array}{l}\text { New to the } \\
\text { firm product }\end{array}$} & 0.182 & 0.163 & 0.179 \\
\hline & $(0.043)^{* * *}$ & $(0.042)^{* * *}$ & $(0.048)^{* * *}$ \\
\hline \multirow{2}{*}{$\begin{array}{l}\text { New to } \\
\text { the market } \\
\text { process }\end{array}$} & -0.012 & -0.002 & 0.007 \\
\hline & $(0.036)$ & $(0.037)$ & $(0.041)$ \\
\hline \multirow{2}{*}{$\begin{array}{l}\text { New to the } \\
\text { firm process }\end{array}$} & -0.045 & 0.012 & -0.061 \\
\hline & $(0.044)$ & $(0.041)$ & $(0.048)$ \\
\hline \multirow{2}{*}{$\begin{array}{l}\text { Organiza- } \\
\text { tional inno- } \\
\text { vation }\end{array}$} & 0.091 & 0.069 & 0.075 \\
\hline & $(0.039)^{* *}$ & $(0.037)^{*}$ & $(0.043)^{*}$ \\
\hline \multirow{2}{*}{$\begin{array}{l}\text { Marketing } \\
\text { innovation }\end{array}$} & 0.044 & 0.062 & 0.029 \\
\hline & $(0.039)$ & $(0.038)$ & $(0.043)$ \\
\hline
\end{tabular}

Notes: ${ }^{*}$ significant at $10 \%,{ }^{* *}$ significant at $5 \%,{ }^{* * *}$ significant at $1 \%$. Vertical refers to suppliers and customers

The first treatment is Only cooperation in information which does not take into account the type of partner. The significant effects for this treatment indicate that firms that cooperate exclusively in obtaining information show a lower R\&D intensity than non-cooperating firms, although this result is only significant at $90 \%$. This would suggest that firms that exclusively cooperate in obtaining information use their networks to absorb the basic initial knowledge that they will require in the future in order to innovate. Meanwhile, firms seem to reduce their investment in R\&D activities while their non-R\&D innovation expenditures remain unaltered. Thus, cooperation in obtaining information seems to be a preliminary state of networking for firms that have not already developed advanced capabilities and have decided to postpone their innovation activities. Moreover, as firms that cooperate exclusively in obtaining information are also more likely to introduce new-to-the-firm products and organizational innovations, it seems that the type of information that firms are looking for through these agreements is related to the knowledge needed to introduce products that already exist in the market, which are also likely to require organizational changes. The positive effect on organizational innovation could also indicate that cooperation in obtaining information may allow firms to build up managerial capabilities that allow firms to adopt flexible structures that facilitate doing, using and interacting modes of learning which can prepare firms to engage in more complex innovation activities in the future (Lundvall, 2007). 
The other two treatments (Only vertical non-ReD cooperation and Only vertical cooperation in information) are very similar variables, as the majority of firms that cooperate exclusively with vertical partners in non- $R \& D$ activities do so for the purpose of obtaining information. This may explain why both treatments show similar effects. As expected, given the previous results, firms with these patterns of cooperation are more likely to introduce new-to-the-firm product and organizational innovations. Therefore, the negative and significant effect at $90 \%$ that we found for the treatment Only cooperating in information on R\&D intensity seems not to be associated with cooperation with vertical partners but with research institutions and competitors. Hence, in developing countries the majority of the firms establish cooperative agreements with suppliers and customers with the purpose of obtaining the required knowledge to introduce products that their competitors already have in the market and this type of innovation seems to require complementary organizational changes. Moreover, although these types of collaborative agreements do not affect the efforts of firms to innovate, as obtaining information is likely to be a preliminary stage in the process of building technological capabilities and also produces organizational changes, it is likely that with the passage of time the knowledge that the firms acquire through these relationships eventually strengthen their capabilities, which would stimulate future innovation activities.

\section{Conclusion}

Since innovation surveys do not provide information on cooperation in innovation activities that are not R\&D, empirical studies on the effects of collaborative innovation have merely evaluated the impact of cooperation in R\&D activities. However, in developing countries, $\mathrm{R} \& \mathrm{D}$ cooperation is only a fringe phenomenon, although most innovative firms are cooperating in other innovation activities such as engineering and design, training, technical assistance, product testing and above all in obtaining information. Firms in developing countries are mainly collaborating in these activities as they do not have sufficient technological capabilities to perform R\&D activities (Fernández-Sastre and Martín-Mayoral, 2016). Nevertheless, by the establishment of cooperative agreements in non-R\&D activities, firms may access external knowledge and resources which may lead to an extension in their technological capabilities and thus to increasing their innovation expenditure and the likelihood of introducing innovations. However, although these innovation linkages may have an impact on firms' innovative behavior and performance their efficacy has not yet been tested.

Drawing on data from the ENAI 2013, which provides information on the different innovation activities in which firms cooperate, this paper evaluates the effects of cooperating in non-R\&D activities on firms' innovation inputs and outputs. Furthermore, it evaluates whether the combination of R\&D and non-R\&D relationships produce additional effects.

In order to estimate the causal effects, we deal with selection bias by using IPW, while in order to prevent our results from being affected by the presence of additional cooperative relationships, we focus on firms that have exclusively one type of relationship. Moreover, since in order to obtain credible standard errors, we need a sufficient number of cooperating firms, we evaluate the impact of the following exclusive cooperative agreements which are the ones most used in Ecuador: Only non-R↔D cooperation, $R \leftrightarrow D$ and non-ReD cooperation, Only cooperation in information, Only vertical non-R\&D cooperation and Only vertical cooperation in information.

Our findings indicate that cooperation in non-R\&D innovation activities positively affects the introduction of new-to-the-firm product, marketing and organizational innovations, while cooperation in both $R \& D$ and non-R\&D activities also have effects on R\&D intensity and new-to-the-market product innovation and also produce greater effects on marketing and organizational innovations. Additionally, firms that cooperate exclusively in obtaining information, which is mainly carried out with suppliers and customers, are more likely to introduce new-to-the-firm product and organizational innovations.

Based on these results, it is argued that non- $R \& D$ cooperation seems to be used by firms to build the minimum essential knowledge base, as it mainly serves to introduce products that already exist in the market. Moreover, the positive effects on marketing and organizational innovations could indicate that non-R\&D cooperation may also allow firms to build up managerial capabilities to engage in more complex innovation activities in the future. By contrast, firms that are also cooperating in R\&D activities seem to be using their networks to strengthen technological capabilities which leads them to invest more in R\&D, allowing them to introduce new-to-the-market product innovations.

Our findings have important policy implications for developing countries, as they suggest that technology policies should not focus exclusively on scientific modes of learning and consequently on formal R\&D. In developing countries, those policies supporting competence building and the absorption of technology and information should be more effective (Chaminade et al., 2010) as the majority of the firms are still accumulating the minimum essential knowledge base to survive in the market (Dutrénit, 2004). Therefore, it may be later on once firms have developed technological and managerial capabilities and the national innovation system contains advanced R\&D organizations and institutions that allow firms to establish satisfactory R\&D networks - that R\&D cooperation should be encouraged.

\section{References}

Anlló, G., \& Suárez, D. (2008). Innovation: Something more than R\&D. Latin American evidence from innovation surveys: building competitive business strategies. Red de Indicadores de Ciencia y Tecnología.

Austin, P., Grootendorst, P., \& Anderson, G. (2007). A comparison of the ability of different propensity score models to balance measured variables between treated and untreated subjects: a Monte Carlo study. Statistics in Medicine, 26(4), 734 - 753.

Chaminade, C., \& Vang, J. (2008). Globalisation of Knowledge Production and Regional Innovation Policy: Supporting Specialized Hubs in Developing Countries, Research Policy, 37(10), 1684-97. 
Chaminade, C., Lundvall, B.Å., Vang, J., \& Joseph, K.J. (2009). Designing innovation policies for development: towards a systemic experimentation-based approach, in: Lundvall, B.Å., Joseph, K.J.,

Chaminade, C., Vang, J. (Eds), Handbook of Innovation Systems and Developing Countries. Edward Elgar Publising Limited, Cheltenham.

Chaminade, C., Lundvall, B., Vang, J., \& Joseph, K. (2010). Innovation policies for development: Towards a systemic experimentarion based approach. Papers in innovation Studies 2010/1, Lund University, CIRCLE - Center for Innovation.

De Faria, P., Lima, F., \& Santos, R. (2010). Cooperation in innovation activities: The importance of partners. Research Policy(39), 1082 - 1092.

Divella, M. (2017). Cooperation linkages and technological capabilities development across firms. Regional Studies, 51(10), 1494-1506

Dutrénit, G. (2004). Building technological capabilities in latecomer firms: A review essay. Science, Technology and Society, 9(2), 209 - 241.

Fernández - Sastre, J. (2015). The effect of national and international R\&D cooperation: differences between manufactures and services. Int. J. Services Technology and Management, 21(1/2/3), 146-162.

Fernández - Sastre, J., \& Martín - Mayoral , F. (2016). The effects of developing countries' innovation support programs: evidence from Ecuador. Innovation: Management, Policy \& Practice.

Figuereido, P. (2001). Technological Learning and Competitive Performance. Cheltenham: Edward Elgar.

Guerzoni, M., \& Raiteri, E. (2015). Demand-side vs. supply-side technology policies: Hidden treatment and new empirical evidence on the policy mix. Research Policy, 44(3), 726 - 747.

Hirano, K., Imbens, G., \& Ridder, G. (2003). Efficient estimation of average treatment effects using the estimated propensity score. Econometrica, 17(4), 1161 - 1189.

Imbens, G. (2015). Matching methods in practice: Three examples. The Journal of Human Resources(50), 373 - 419.

Lall, S. (1992). Technological capabilities and industrialization. World Development, 20(2), 165 - 186.
Landry, R., \& Amara, N. (2002). Effects of sources of information on the on novelty of innovation in Canadian manufacturing firms: Evidence from the 1999 Statistics Canada Innovation Survey. Quebec, Canada.

Molina - Domene, M., \& Pietrobelli, C. (2012). Drivers of technological capabilities in developing countries: An econometric analysis of Argentina, Brasil and Chile. Structural Change and Economic Dynamics.

Radicic, D., Douglas, D., Pugh, G., \& Jackson, I. (2015). Cooperation for innovation and its impact on technological and non-technological innovations: empirical evidence for European manufacturing SMEs. ResearchGate.

Rosenbaum, P. (2005). Propensity score. In P. Armitage, \& T. Colton (Eds.), Encyclopedia of Biostatistics (pp. 4267 - 4272). Boston: Wiley.

Rubin, D., \& Rosenbaum, P. (1983). Assessing sensitivity to an unobserved binary covariate in an observational study with binary outcome. Journal of the Royal Statistical Society, 45(2), 212 - 218.

Sánchez-González, G. (2013, June 17-19). Cooperation and non-technological innovations. 35th DRUID Celebration Conference. Barcelona, Spain.

Simao, L., \& Franco, M. (2015). The effect of R\&D cooperation on organizational innovation: An empirical study of portuguese enterprises. In L. Carmo, J. Ferreira, H. Lawton, \& S. Bagchi-Sen, Handbook of Research on Global Competitive Advantage through Innovation and Entrepreneurship (pp. 352 - 370). IGI Global.

Shin, K., Kim, S.J., Park, G. (2016). How does the partner type in R\&D alliances impact technological innovation performance? A study on the Korean biotechnology industry. Asian Pacific Journal of Management. 33 (1), 141-164.

Sousa, A., Braga, M., \& Meyer, L. (2015). Impact of cooperation on the R\&D activities of Brazilian firms. Procedia Economics and Finance, 24, 172 - 181 .

Zhou, K., \& Wu, F. (2010). Technological capability, strategic flexibility, and product innovation. Strategic Management Journal, 31(5), 547- 561 . 


\section{Appendix}

Appendix 1. Covariates in the probit propensity score model

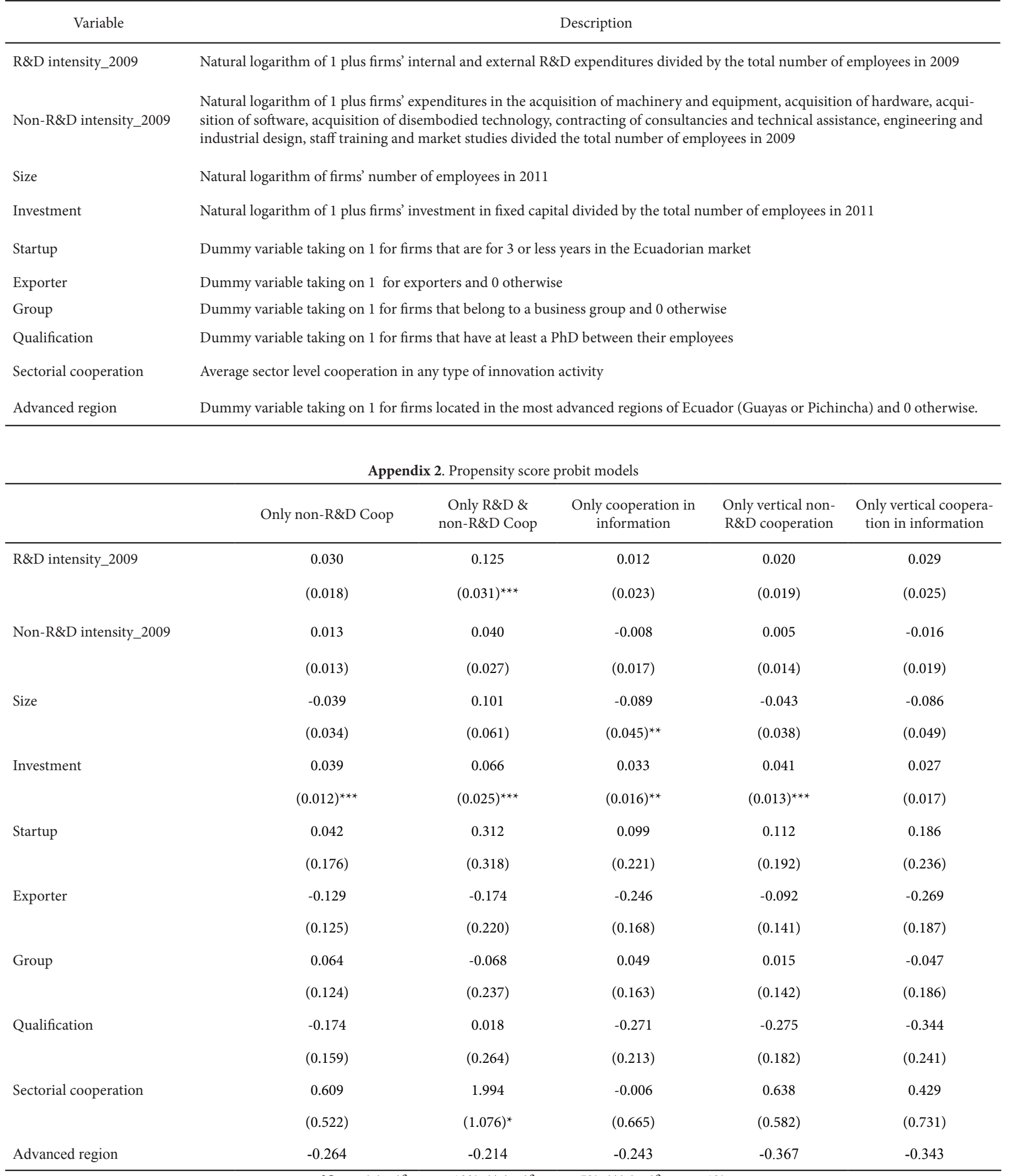

Notes: ${ }^{*}$ significant at $10 \%,{ }^{* *}$ significant at $5 \%,{ }^{* * *}$ significant at $1 \%$ 
Appendix 3. Covariates balance test

\begin{tabular}{|c|c|c|c|c|c|c|c|c|c|c|c|c|}
\hline & \multicolumn{4}{|c|}{ Only cooperation in information } & \multicolumn{4}{|c|}{ Only vertical non- $R \& D$ cooperation } & \multicolumn{4}{|c|}{ Only vertical cooperation in information } \\
\hline & \multicolumn{2}{|c|}{$\begin{array}{c}\text { Standardized } \\
\text { differences }\end{array}$} & \multicolumn{2}{|c|}{ Variance ratio } & \multicolumn{2}{|c|}{$\begin{array}{c}\text { Standardized } \\
\text { differences }\end{array}$} & \multicolumn{2}{|c|}{ Variance ratio } & \multicolumn{2}{|c|}{$\begin{array}{c}\text { Standardized } \\
\text { differences }\end{array}$} & \multicolumn{2}{|c|}{ Variance ratio } \\
\hline & $\begin{array}{c}\text { Before } \\
\text { IPW }\end{array}$ & $\begin{array}{l}\text { After } \\
\text { IPW }\end{array}$ & $\begin{array}{l}\text { Before } \\
\text { IPW }\end{array}$ & $\begin{array}{l}\text { After } \\
\text { IPW }\end{array}$ & $\begin{array}{l}\text { Before } \\
\text { IPW }\end{array}$ & $\begin{array}{l}\text { After } \\
\text { IPW }\end{array}$ & $\begin{array}{l}\text { Before } \\
\text { IPW }\end{array}$ & $\begin{array}{l}\text { After } \\
\text { IPW }\end{array}$ & $\begin{array}{l}\text { Before } \\
\text { IPW }\end{array}$ & $\begin{array}{l}\text { After } \\
\text { IPW }\end{array}$ & $\begin{array}{l}\text { Before } \\
\text { IPW }\end{array}$ & $\begin{array}{l}\text { After } \\
\text { IPW }\end{array}$ \\
\hline R\&D intensity_2009 & 0.025 & -0.021 & 1.108 & 1.003 & 0.099 & -0.054 & 1.236 & 0.965 & 0.053 & -0.043 & 1.242 & 1.035 \\
\hline $\begin{array}{l}\text { Non-R\&D intensi- } \\
\text { ty_2009 }\end{array}$ & -0.015 & -0.003 & 1.040 & 0.997 & 0.105 & -0.025 & 1.125 & 1.006 & -0.028 & -0.009 & 1.054 & 0.995 \\
\hline Size & -0.253 & -0.005 & 0.771 & 1.065 & -0.131 & 0.024 & 0.925 & 1.094 & -0.285 & 0.004 & 0.760 & 1.110 \\
\hline Investment & 0.129 & 0.009 & 0.982 & 1.059 & 0.235 & 0.023 & 1.023 & 1.146 & 0.093 & 0.003 & 0.979 & 1.044 \\
\hline Start-up & 0.056 & -0.003 & 1.223 & 0.988 & 0.071 & -0.029 & 1.285 & 0.911 & 0.092 & -0.012 & 1.381 & 0.962 \\
\hline Exporter & -0.200 & 0.008 & 0.639 & 1.021 & -0.084 & 0.002 & 0.845 & 1.004 & -0.219 & 0.006 & 0.606 & 1.017 \\
\hline Group & -0.053 & 0.008 & 0.887 & 1.019 & -0.044 & 0.030 & 0.905 & 1.074 & -0.107 & 0.014 & 0.777 & 1.039 \\
\hline Qualification & -0.141 & 0.004 & 0.611 & 1.017 & -0.133 & -0.006 & 0.631 & 0.977 & -0.165 & 0.013 & 0.552 & 1.059 \\
\hline Sectorial cooperation & 0.038 & 0.008 & 0.976 & 0.988 & 0.135 & -0.007 & 0.943 & 1.055 & 0.097 & 0.001 & 0.958 & 1.028 \\
\hline Advanced region & -0.233 & 0.007 & 1.197 & 0.996 & -0.346 & 0.021 & 1.250 & 0.995 & -0.310 & 0.028 & 1.239 & 0.991 \\
\hline
\end{tabular}

